\title{
STRESS PROTEINS: NOMENCLATURE, DIVISION AND FUNCTIONS
}

\author{
Petr Kopeček ${ }^{a}$, Karla Altmannováa, Evžen Weigl*b
}

\author{
a Department of Biology \\ ${ }^{b}$ Department of Immunology, Medical Faculty, Palacký University, 77515 Olomouc, Czech Republic
}

Received: September 20, 2001

Key words: Stress proteins / Hsp / Molecular chaperon

The heat shock response, characterized by increased expression of heat shock proteins (Hsps) is induced by exposure of cells and tissues to extreme conditions that cause acute or chronic stress. Hsps function as molecular chaperones in regulating cellular homeostasis and promoting survival. If the stress is too severe, a signal that leads to programmed cell death, apoptosis, is activated, thereby providing a finely tuned balance between survival and death. In addition to extracellular stimuli, several nonstressful conditions induce Hsps during normal cellular growth and development. The enhanced heat shock gene expression in response to various stimuli is regulated by heat shock transcription factors.

Prokaryotic and eukaryotic cells react to exposition unfavourable conditions of the outer environment by increased synthesis of the stress proteins. The structures and functions of these proteins are evolutionary highly conserved and they are present in different variations in the cells of all living organisms. Increased synthesis of the stress protein apparently correlates with an organism's resistance to stress and with a level of own stress $^{1}$.

Ritossa described cellular stress response for the first time in 1962. He observed the characteristic puffs that indicated a transcriptional activity on discreet chromosomal loci in salivary glands of Drosophila melanogaster at an increased temperature ${ }^{2}$. Proteins coded by the genes in described loci were named by Tissieres et al. as the heat shock proteins (hsp), because their increased synthesis was reached by a sudden increase in temperature ${ }^{3}$. Other studies showed that an expression of hsp is induced by many various factors in the cell. These factors include: a) changes in: temperature, $\mathrm{pH}$, osmolarity, and radiation, and b) higher concentration of heavy metals, ethanol, antibiotics, fatty acids and reactive oxygen forms.

The stress response can be invoked by a change of partial gas pressure in the atmosphere, by absence of nutrients or by infection in higher organisms. Thus, hsp resp. stress proteins enable cells to survive when there are unfavourable conditions in the outer environment $^{4,5,6,7}$.

There are two main functions of stress proteins which are essential for reparation of each living cell which is damaged by stress. They are: 1) the participation in protein folding into their correct tertiary structure, incorporation of polypeptides into intracellular membranes or in transport of proteins across those membranes $\left.{ }^{8,9}, 2\right)$ the function of some the stress pro- teins in ubiquitin-dependent protein degradation; ubiquitin itself also belongs to the hsp super-family ${ }^{10,11,12,13,14}$.

Although during stress the synthesis of the stress proteins has increased considerably, a lot of the stress proteins are expressed as the constitutive proteins, and they play the significant role even in the cells which are not exposed to the stress factors ${ }^{15}$. The stress proteins have also been important models for these studies, not only of stress response in the last years ${ }^{16}$.

They have been studied in: regulation of transcription $^{17,18}$, evolution ${ }^{19}$, embriogenesis ${ }^{20,21,22}$, the ageing process $^{23,24}$ and apoptosis ${ }^{25,26,27,28}$.

\section{NOMENCLATURE AND THE BASIC DIVISION OF STRESS PROTEINS}

The study of Tissieres et al. (1974) introduced the term "heat shock proteins", and it belongs to the beginning of research on the stress proteins ${ }^{3}$. In a context of current knowledge, the term "protein heat shock proteins", especially in eukaryotes, is used rather as a historical name. Particularly, it still overlaps with the logically evidently more correct term "stress proteins". This name specifies all the group of proteins generally where expression has increased due to an incidence of the stress factors. An abbreviation for the stress protein(s) "hsp" already remains in use. Above all, there are some proteins in prokaryotes where synthesis is affected by the heat shock, and they are denoted like heat shock proteins only, although they may be produced due to another stress factors than the heat stress as well ${ }^{29}$. Sometimes we can see another abbreviation, "hsc" (heat shock cognates), which has been used for the constitutive forms of hsp. Those forms of hsp are 
also present at non-stressed cells, and in contrast to the majority of other proteins, their intracellular concentrations have been increased during the heat shock.

In eukaryotic cells, different stress factors induce the synthesis of another, even if similar proteins or the same proteins are localised in another cellular compartment $^{30}$. This has contributed to the introduction of a great number of trivial names and abbreviations, mostly derived from initial letters of the English terms. They describe stress factors or functions of the certain proteins themselves. For example, grp78 is the abbreviation for the stress protein that is induced by an exhaustion of glucose or by an abundance of calcium ions in the outer environment. Grp78 can be present under normal (nonstress) conditions and is denoted as hsc78, otherwise known as hsp78. The identical protein is found underneath the abbreviation $\mathrm{BiP}$ (binding protein), because it binds heavy chains of immunoglobuline molecules ${ }^{31}$. Another example can be the DnaK protein in Escherichia coli, which is linked with its participation upon DNA replication $^{32}$.

The term "chaperone" is used very often. This term points out the function of the protein directly. It concerns the stress as well as non-stress proteins, which accompany unfolded polypeptides during their cellular transport, and they make passage of proteins through the membranes possible or their integration into cellular organelles. A similar, well-known term, "chaperonin" is the alternative name for the GroEL protein. It is abbreviated as "cnp60" or "hsp60". The chaperonins are present in bacteria as well as in mitochondria and in chloroplasts, denopting the organelles probably originated from the endosymbiosis ${ }^{33}{ }^{34}$. An identical term is also used for GroES (cnp10), which has some sequence similarity with GroEL and also for some other proteins e. g. hsp58 $8^{35}, \mathrm{P} 1^{36}, 65 \mathrm{kDa}$ antigen ${ }^{37}$ etc. Chaperonins, according to Coates et al. ${ }^{38}$ would be divided into two "sub-families", GroE and TCP1.

This increased knowledge we have about stress proteins has lead to division of the hsp super-family into specific families ${ }^{39}$. The significant determinant criteria are the molar masses of proteins ${ }^{40}$. The important sequence and functional homologies were observed among the members of individual hsp families as well ${ }^{41,42}$. The division of hsp into the families is not standardised precisely yet. Earlier dividing of families: hsp90, hsp70, hsp60 and small hsp ${ }^{43}$ has been extended step by step to hsp110, hsp100, hsp90, hsp70, hsp60, hsp40, hsp10 and small hsp families ${ }^{1,44}$. Numeric indexing represents the protein molecular masses in $\mathrm{kDa}$. The stress proteins are registered into appropriate families according to their approximate molecular masses, their functions in the cells and their homologies in the primary structures.

Currently, we have the largest amount of information about the stress proteins hsp90, hsp70, hsp60 and small hsp families. That is why, the major attention will be dedicated to them in the following text.

\section{1 hsp 90}

Hsp90 (hsp83) is the most abundant cytosolic protein in the eukaryotic cells. Its homologues were found in the endoplasmic reticula (ER) of higher eukaryotes (grp94 also called endoplasmin) and in prokarytic cells (HtpG). Hsp90 exists in vivo, obviously as a dimer and it co-exists as a cytosolic protein in higher eukaryotes in two homologue isoforms. Those are indicated as alpha and beta and are produced in the same quantity. In E. coli the HtpG $(68 \mathrm{kDa})$ differs from hsp90 by the absence of a charged area of approximately 50 amino acids, which is characteristic for the other hsp90 homologues ${ }^{45}$.

Under physiological conditions, hsp90 was found in association with several intracellular proteins including calmodulin, actin, tubulin, several kinases, and some receptor proteins ${ }^{46,47,48,49}$. Significant interest is dedicated to the pivotal role of hsp90 into the regulation of hormonal receptors ${ }^{50,51,52,53}$. Receptors what aren't bounded to their hormones are probably bound to hsp90 shortly after their translation ${ }^{54}$. In case of the glucocorticotropic receptor, binding of hsp90 leads to an enhancement capability of the receptor to bind to the steroid hormone ${ }^{55}$. The C-terminal region of the hsp90 molecule is responsible for the receptor binding ${ }^{56}$.

Formation of the complex of hsp90 with non-receptor tyrosine kinases was also described as viral oncoprotein $\mathrm{v}-S c r^{57,58}$. Hsp90 has even chaperone function ${ }^{59}$ that is comparable to GroEL function and can suppress an aggregation of proteins during their repeated assembling into their tertiary structures ${ }^{60}$. Cytosolic hsp 90 aggregates with hsp 70 under the stress conditions and it is suggested that interaction occurs of both hsp(s) with unfolded proteins ${ }^{49}$.

\section{2 hsp 70}

Proteins in the hsp70 family are known for their ability to bind peptide chains. They act in: 1) a protection of the nascent proteins, 2) a protein transport across the membranes, 3) repeated assembling of unfolded proteins, and 4) the protein degradation ${ }^{61,62,63,64}$.

The structure of hsp70 consists of a domain with ATPase activity and a domain capable to bind peptides ${ }^{65}$. By roentgenographic analysis it was found that the ATPase domain has high structural homology with ATPase domains of hexokinases ${ }^{66}$ and $\operatorname{actin}^{67}$. The domain that is capable to bind peptide was modelled on the structure of MHC I antigen ${ }^{68}$. MHC I antigen selection can also be connected by localisation of the genes coding for some hsp70 inside a gene region of the MHC complex $^{69}$. The localisation above mentioned was found in man experimentally ${ }^{70,71}$. For instance $\mathrm{BiP} /$ grp 78 was localised on the $9 q 34$ position $^{72}$. These genes were also identified in other species, e.g. rat $^{73}$, goat ${ }^{74}$, cattle $^{75}$, pig $^{76}$, and frog ${ }^{77}$. The genes coding for hsp70 are also located in eukaryotes in the different loci resp. chromosomes and form the multigene families ${ }^{69}$. The high grade of structural homology exists in the hsp70 family, e.g. in man, hsp70-1 gene is distanced from gene hsp70-2b by 
only $8 \mathrm{~kb}$, and both coding for the protein with the same primary structure ${ }^{71}$.

There is approximately 50 percent homology in eukaryotic hsp70 and prokaryotic DnaK protein in E. coli ${ }^{78}$. This protein performs its functions frequently in co-operation with DnaJ protein and GroE in E. coli ${ }^{79}$, $80,81,82,83,84$. Genetic and biochemical study results support the hypotheses that proteins of DnaJ type co-operate with certain hsp70 proteins in all organisms $\mathrm{s}^{85}$. For instance, the proteins Kar2p (homologue DnaK) and Sec63p (DnaJ homologue) participate on a protein transport to the ER in Saccharomyces cerevisiae ${ }^{86}$.

This confirms a considerable evolutionary conservancy of the entire hsp super-family ${ }^{62}$. Thus it could be expected that an immune system will recognise the stress proteins as the body's own antigens and therefore, the immune responses against hsp will be rare. Nevertheless, if the contrary is true ${ }^{87,88,89,90}$ and the stress proteins from hsp60 and hsp70 families belong to the group of immunodominant antigens ${ }^{91,92,93}$.

\section{3 hsp60}

In 1981 the essential functions of GroEL were described in bacterial growth in head morfogenesis of lambda and T4 phages and in the tail formation of T5 phages $^{94}$. The chaperonins (the group of stress proteins belonging to the hsp60 family) have significant roles in polypeptide folding and in protein transport in the cells as well ${ }^{8}$. These proteins are not only in bacterial cells, but also in mitochondria and in chloroplasts of eukaryotic cells, and the genes coding for hsp60 form a part of the nuclear genome ${ }^{35,}{ }^{95,}{ }^{96}$. Similar structural motifs were observed among mitochondrial hsp60, plastid hsp60, and hsp60 in E. coli ${ }^{35,97}$. Although hsp60 forms a twolayer heptamer ring in chloroplasts and in the majority of mitochondria ${ }^{98}$, the ovary cells of the Chinese hamster ${ }^{99}$ and moth sperms $\mathrm{s}^{100}$ have the single heptamer rings of hsp60 in their mitochondria. Chloroplasts in contrast to mitochondria and E. coli, which contain only one type of hsp60 polypeptide ${ }^{95,}{ }^{96}$, have roughly identical quantity of the two diverse forms of hsp60 polypeptides alpha and beta ${ }^{101,102}$. The chloroplast hsp60 was originally identified like a component that has appeared in biosynthesis of ribulose biphosphate karboxylase (Rubisco), where it binds the unfolded polypeptides before they form the holoenzyme ${ }^{103}$.

Generally, chaperonins are able to form stable complexes with proteins, which are imported to chloroplasts and to mitochondria ${ }^{98}$. They perform their chaperone function also in co-operation with the other molecules, e. g. cnp10 and hsp70 $0^{81,104}$. Hsp60 also has other important functions in an immune response due to its already mentioned immunodominant properties ${ }^{91,92,93}$. Furthermore, bacterial hsp60 and hsp70 take a part in regulation of gene transcription coding for the stress proteins ${ }^{105}$.

\section{TRANSCRIPTION OF GENES CODING FOR HSP}

A significant correspondence in the stress response of different organisms exists. Structural and functional similarities were described among members of hsp families $^{1}$. Certain similarities can be seen in the regulation of stress gene expression as well. Why is considerable attention given to the regulation of transcription of the genes coding for the stress proteins at all? During the heat shock, the transcription of those genes is increased as much as 100 times $^{106}$ that offers the following opportunities: 1) detection of specific regulation components and quantitative evaluation of an expression in time, and an understanding to their role in transcription as well ${ }^{18,107}, 2$ ) creation of the model on an investigation of kinetics and mechanisms of these processes; because genes coding for the stress proteins are activated rapidly by proteins, which are present in non-inducted cells ${ }^{17}$, 3) obtaining the information about the primary structures of DNA elements and protein factors, which take a part on transcription control and about their localisation into the chromatin $\left.{ }^{108}, 4\right)$ an application of the knowledge on hsp gene transcription that has a general significance for the study of transcription control, because some promoters of hsp genes are assembled from the elements, which can be found in the promoters of other genes ${ }^{17}$.

From the presented specifications, a common significance of the investigation of transcription of the genes coding for the stress proteins and their exploitation for better understanding to mechanisms of transcription to make a general image of the stress protein expression. Due to the different mechanisms in prokaryotes and eukaryotes, they will be discussed separately in this text.

\subsection{Transcription of genes for the stress proteins in prokaryotes}

Most of the informations about the transcription of genes for the stress proteins were obtained from the studies using bacterium $E$. coli. The cells respond to increased levels and activity of the transcription factor - sigma32 (32 indicates the molecular mass in $\mathrm{kDa}$ ) by increased transcription in the genes coding for the stress proteins. Sigma32 factor is coded by the gene rpoH and controls transcription of about 20 hsp, e.g. DnaK, DnaJ, GroEL and GroES (Fig. 1). These proteins were identified by 2 -D electrophoresis ${ }^{105}$. Major transcription factor is sigma70 in the prokaryotic cells in addition to the afore mentioned sigma32 ${ }^{109}$. If the level of sigma70 is reduced, hsp expression increases and leads to the conception of competition for RNA polymerase between sigma70 and sigma32 factors ${ }^{105}$. Regulation function of the sigma32 is, above all, based on its synthesis, activa- 
tion and degradation ${ }^{110}$. Under normal conditions, sigma32 levels are very low, but its half-life is getting longer at the increased temperature ${ }^{111}$. Quantity of the sigma32 is influenced by negative feedback as well e.g. by DnaK. Without the presence of DnaK the lifetime of sigma32 is 10-30 times longer. Similar effect on the sigma32 level was also demonstrated with the presence of DnaJ and GrpE. Furthermore sigma32 activity is dependent on temperature ${ }^{81}$.

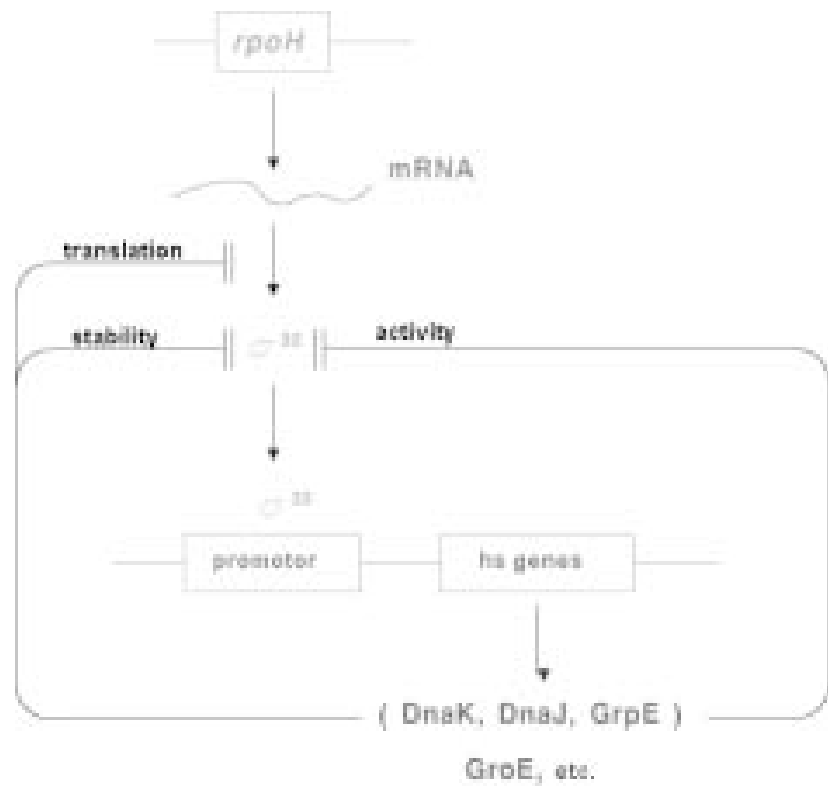

Fig. 1. The scheme of the regulation of hsp expression in prokaryotes $^{158}$.

The gene coding for sigma32 (rpoH) has at least 4 promoters. Three of them, P1, P4 and P5 are transcribed in attendance of sigma $70^{112}$, while P3 is transcribed by RNA polymerase that contains sigma 24 factor, which is more active under very high temperature ${ }^{113}$. P1 is the most distant promoter and also the strongest one. Its activity is not evidently regulated, but its -35 region coincides with the neighbour fts $\mathrm{X}$ gene. Therefore, there is a hypothesis of the possible connection with transcription of fts gene, which is perhaps mediated by DnaA protein ${ }^{114,115,116 .}$ P1 and P4 promotors are responsible for the majority of the transcription of $\mathrm{rpoH}$ gene during vegetative conditions. In addition $\mathrm{P} 4$ embodies 2-3 times higher activity under elevated temperature ${ }^{112}$. P3 and P4 promotors bind the DnaA protein, which specifically inhibits the transcription from those promoters $^{117}$. P5 is a relatively weak promoter, its effect boosts in the absence of glucose, or with ethanol addition. This promoter requires the presence of cAMP and of cAMP receptor protein in vitro ${ }^{118}$, but their presence is not necessary during an absence of carbon ${ }^{119}$. P3 is mostly active in extreme conditions, e. g. at lethal temperatures (over $50{ }^{\circ} \mathrm{C}$ ), when the other transcription factors are apparently inhibited ${ }^{158}$. Several bacterial promoters have the sequence similarities to rpoHp3. One of the bacterial promoters is the htrA gene coding for $\operatorname{degP}$ protease (it acts under the higher temperature). This is transcribed with sigmaE (sigma24) in vitro ${ }^{120,121}$. These results imply that the second regulone for hsp expression controlled by sigmaE is co-existed in E. coli. This regulone can intensify or supplement the effect of sigma32 regulone, which is expressed on the basis of another stress.

\subsection{Transcription of genes for the stress proteins in eukaryotes}

Eukaryotic stress genes are generally controlled by HSE (heat shock elements) and hsf (heat shock factors), which are bound to them closely ${ }^{20}$. All of the HSE contain a basic motif of sequence 5'-NGAAN-3'. These sequences go subsequently in reversing orientation and their number is different, e. g. 4 HSE were found, and each of them contains 3 or 4 basic units in the hsp 70 gene of $D$. melanogaster. On the other hand, 7 or 8 basic units were found in the hsp83 gene, which are only in one HSE. An insertion of 5bp can occur among repeated units in HSE as well ${ }^{122}$. The basic unit of $5 \mathrm{bp}$ can have a different primary structure. This is significant for the strength of the HSE region. The second position (G) is absolutely conserved, while the positions 3 and 4 (A) are less conserved. Substitutions were also found on the first position. Mostly, there is appeared (A) there, (T) is rare. Such substitution - (T) instead (A) leads to the significant decrease of hsp70 expression. Chemical modifications of (A), and also (T) have caused in both cases a lower affinity of hsf to the modified HSE regions. Position 5 is the least conserved, but it also affects activity of transcription ${ }^{17}$.

Hsf are functionally conserved in an entire eukaryotic empire. They are present as monomers in non-stressed cells, while they form trimers in the stressed cells ${ }^{18}$. The trimer is distinguished by a higher asymmetry compared to the monomeric form ${ }^{123}$. Different numbers of genes may code for hsf, e. g. one gene coding for hsf is in Drosophila melanogaster ${ }^{124}$, with vertebrates having several similar genes for $\mathrm{hsf}^{18}$. Heat shock response is mediated by hsf1 in $\operatorname{man}^{107}$. Hsf structures in different species are diverse with an exception of two conserved regions on their N-ends, which represent DNA binding and trimerisation domains ${ }^{124}$.

Interaction hsf-HSE can contain a various number of the basic HSE units. The smallest detectable part of HSE bounded to hsf is $10 \mathrm{bp}$ long, and it exists in configuration "tail-to-tail" or "head-to-head". Hsf covers these parts in same manner. Hsf are also constitutive proteins in monomeric forms in eukaryotes (with the exception of yeasts $)^{125}$. They are activated during the heat shock and form the trimers ${ }^{17,107}$. Hsf are redistributed from non-specific places on chromatin to separated chromosomal targets. A subpopulation of hsf molecules is transferred from the cytoplasmatic compartments into the nuclei during heat shock as well ${ }^{18}$. Thus, hsf and HSE interact if the hsf is in trimer form ${ }^{126}$. In yeasts ( $S$. cerevisiae), the trimer form of hsf is present 
in its constitutive state, and remains bound on HSE during both normal and stress conditions. The stimulation of transcriptional activity of hsf in $S$. cerevisiae is apparently connected with phosphorylation in its serine and threonine residues. Binding activity of hsf is induced by various agents, which affect protein structure. These agents include: heat, slightly acidic $\mathrm{pH}(6,5)$ or presence of detergents ${ }^{107,127}$.

Original hypothesis of hsf activation in vitro is based on direct formation of an oligomeric state (trimer) ${ }^{128}$. The impossibility of dissociation of trimers to the monomeric forms in normal conditions shows that it cannot be a reversible one-component system. This leads to an idea of another intracellular component, which can act in the folding of nascent hsf polypeptide during its synthesis, and during disintegration of hsf trimer, when the cell is returned back to the normal conditions ${ }^{17}$. This offers also an idea of possible participation of molecular chaperones including some other hsp ${ }^{129}$ (Fig. 2).

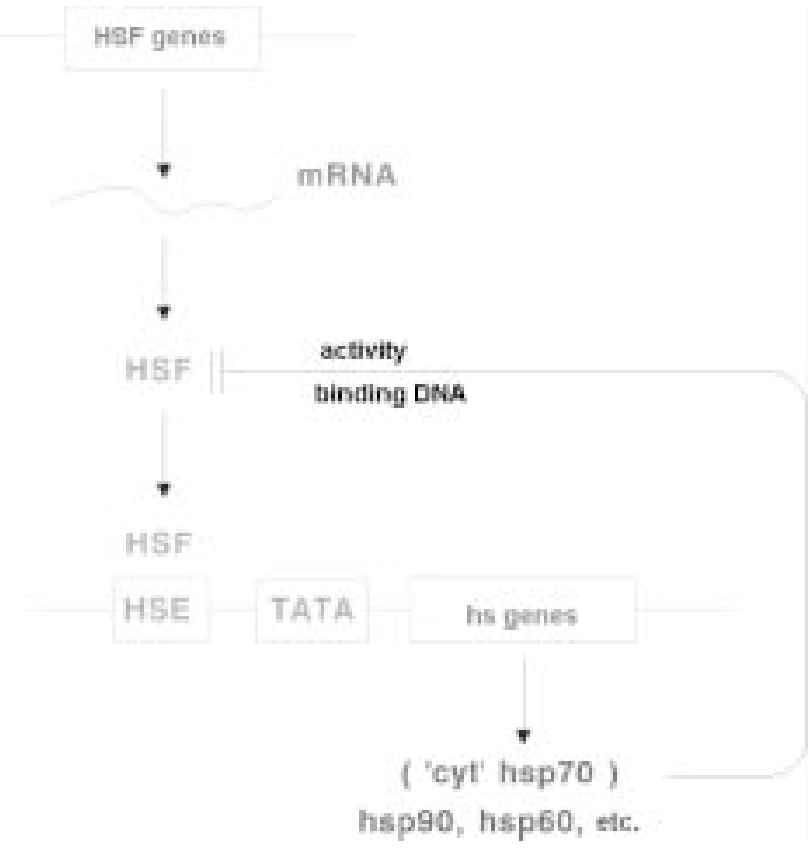

Fig. 2. The scheme of the regulation of hsp expression in eukaryotes $^{158}$.

\section{BIOLOGICAL FUNCTION OF THE STRESS PROTEINS}

Principal roles of the stress proteins are reparation, protection, or elimination of damaged proteins in the cells. In this context there are generally two important biological functions: 1) the function of molecular chaperones $^{8,9}$, and 2) the function of the stress proteins in protein degradation ${ }^{10,11,12,13,14}$.

\subsection{Molecular chaperones}

The significance of the molecular chaperones is in their assessment in a protein folding or refolding to their native conformations by stabilising of their partly denatured states ${ }^{9,130,131}$. Chaperones contain no specific information for polypeptide folding, but they are able to prevent production of aggregates from the nascent polypeptides $^{34,132}$. It could be noticed that other heat induced proteins like peptide-isomerases and disulphid-isomerases act directly in a formation of higher protein structures ${ }^{133}$, and they are called "foldases" trivially ${ }^{134}$.

Chaperones from the hsp70 family have a dominant role in complex formation with nascent polypeptides on the ribosomes and thus inhibit their premature folding since a translation is terminated ${ }^{37}$. Hsp70 has not only function in the production of mentioned complexes, but it also participates in a transport function and in polypeptide folding ${ }^{135}$. Basic function of hsp70 is the binding of unfolded proteins and their release. It proceeds in an ATP dependent cycle ${ }^{136,137}$, in which: 1) partially unfolded protein associates with $\mathrm{C}$-terminal domain hsp $70^{138,139}$, 2) binding of co-chaperone hsp40 started a dissociation of ATP with N-terminal domain of hsp $70^{140}$, which leads to a conformational change (hsp70/ADP complex), 3) hsp40 dissociates, 4) BAG - 1 protein binds, 5) ADP/ATP exchange is initiated, 6) BAG-1 dissociates, 7) bounded proteins are released finally (fig. 3.).

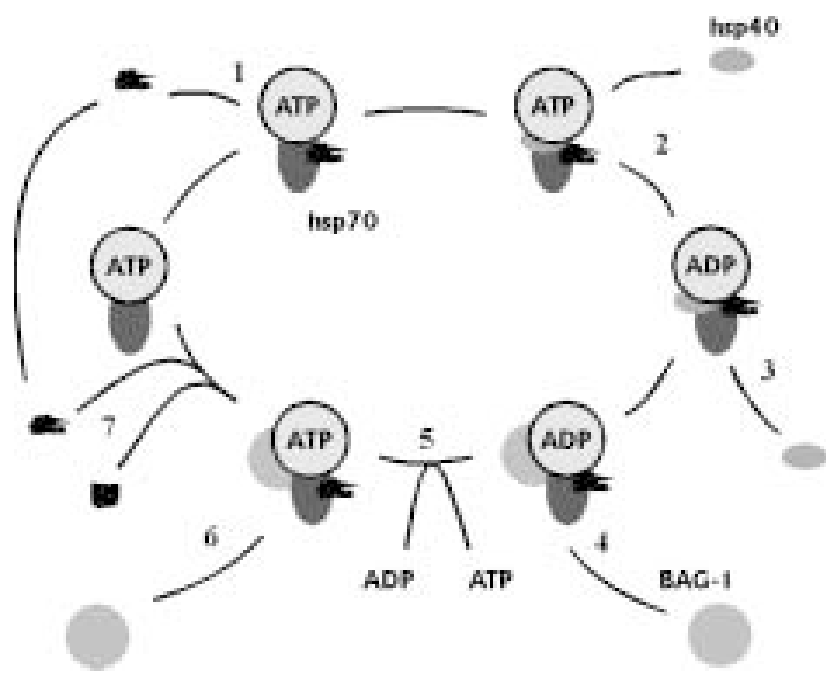

Fig. 3. Hsp 70 chaperone machine ${ }^{34}$.

Mostly, the proteins require an accomplishment of their correct native conformation to pass for several times by the described cycle ${ }^{34}$. This cycle is called the hsp70 chaperone machine, in which hsp70 co-operates with hsp40 and BAG-1 proteins ${ }^{141}$.

Complex of the stress proteins with already synthesised protein enables transport of this protein into cellular organelles ${ }^{9,142}$. 
Chaperones are able to stabilise the proteins that are damaged by influence(?) of the stress factors, and they participate into their renaturation. This function was described in detail for GroEL protein ${ }^{55,143}$.

GroEL recognises hydrophobic residues on the surface of partly denatured proteins ${ }^{143}$ and introduces them into the central cavity of its heptameric ring that is formed by $57-\mathrm{kDa}$ units ${ }^{144,145,146}$. Proteins bound in this GroEL complex are protected against the effects of proteolytic enzymes ${ }^{144}$. This "cage" model suggests a protein folding through a creation of the inner microenvironment, in which a protein folding can continue since the protein is protected against aggregation ${ }^{147}$. Another interactive alignment model was found on the limiting number of the steps in ATP dependent cycle ${ }^{148}$ and on an intramolecular reorganisation of protein segments $^{149}$. Its principle is more similar to the mechanism of hsp70 chaperone function. Both models do not exclude each other. Both models include co-operation with a co-chaperone GroES ${ }^{150,151}$, resp. co-operation of cnp60 with cnp $10^{152}$ in folding of partly unfolded proteins ${ }^{98,146,153}$.

\subsection{Protein degradation}

Molecular chaperones take a part in degradation of irreversibly damaged proteins ${ }^{43}$. The proteins, which are determined to degradation, have to be in a soluble state to be recognised by proteolytic enzymes. hsp preserves such a state and therefore the chaperone function of hsp is essential not only for the repair of damaged proteins, but also for their degradation ${ }^{154}$.

Hsp have other functions in the degradation process. The stress protein - DegP has not only a chaperone function, which dominates under lower temperatures, but also has proteolytic activity under higher temperatures ${ }^{155}$.

The pivotal function of ubiquitin in protein degradation is a little distinct from the function of molecular chaperones. Ubiquitin is ranked among the hsp and was found in all of the eukaryotic organisms ${ }^{10,11,12,13,14}$. Ubiquitin mRNA contains several subsequently repeating copies of the ubiqutin gene. The level if this mRNA can raise $2-50$ times during the stress ${ }^{156}$. Ubiquitin is formed by 76 amino acids and it is probably the most conserved protein in evolution ${ }^{157}$. The difference between ubiquitin molecules in man and in nematodes was only one amino acid $^{156}$.

The C-part of ubiquitin binds by isopeptide bound to etha-amino groups of lysine residues in substrate proteins. By the same way, it repeatedly binds to the already bounded ubiquitin molecules ${ }^{11}$. Thus it forms the side chains on the substrate proteins, which are recognised by multi-subunit protease, known as $26 \mathrm{~S}$ proteasome. When the "marked" substrate proteins, including ubiquitine, are broken down the ubiquitin monomers are ready for the further cycle ${ }^{156}$.

\section{ACKNOWLEDGMENTS}

Thanks are due to Ms. Rhianne Turner for help with the language correction.

Supported by the Grant 11811151100002.

\section{LITERATURE}

1. Feder, M. E. (1999) Heat-shock proteins, molecular chaperones, and the stress response: evolutionary and ecological physiology. Annu Rev. Physiol. 61, 243-282.

2. Ritossa, F. (1962) New puffing pattern induced by temperature shock and DNP in Drosophila. Experientia 18, 571-573.

3. Tissieres, A., Mitchell, H. K., Tracey, U. M. (1974) Protein synthesis in salivary glands of $D$. melanogaster. Relation to chromosome puffs. J. Mol. Biol. 84, 389-398.

4. Polla, B. S. (1988) A role of heat shock proteins in inflamation? Immunol. Today 9, 134-137.

5. Donati, Y. R., Slosman, D. O., Polla, B. S. (1990) Oxidative injury and the heat shock response. Biochemical Pharmacology 40, 2571-2577.

6. Boreham, D. R., Mitchel, R. E. (1994) Regulation of heat and radiation stress responses in yeast by hsp-104. Radiat Res 137, 190-195.

7. Sheikh-Hamad, D., Garcia-Perez, A., Ferraris, J. D., Peters, E. M., Burg, M. B. (1994) Induction of gene expression by heat shock versus osmotic stress. Am. J. Physiol. 267, F28-F34.

8. Van der Vies, S. M., Gatenby, A. A., Viitanen, P. V., Lorimer, G. H. (1993) Molecular chaperones and their role in protein assenbly. In Protein folding in vivo and in vitro. (Cleland, J. L., ed.), American Chemical Society, Washington DC, pp. 72-83.

9. Mathew, A., Morimoto, R. I. (1998) Role of the heat-shock response in the life and death of proteins. Ann. N. Y. Acad. Sci. 851, 99-111.

10. Burel, C., Mezger, V., Pinto, M., Rallu, M., Trigon, S., Morange, M. (1992) Mammalian heat shock protein families. Expression and functions. Experientia 48, 629-634.

11. Peters, J. M. (1994) Proteasomes: protein degradation machines of the cell. Trend Biochem. Sci. 19, 377-382.

12. Hilt, W., Wolf, D. H. (1995) Proteasomes of the yeast $S$. cerevisiae: genes, structure and functions. Mol. Biol. Rep. 21, 3-10.

13. Haas, I. G. (1995) Protein-mediated protein maturation in eukaryotes. FEBS Lett 369, 72-75.

14. Callis, J. (1995) Regulation of protein degradation. The Plant Cell, 7, 845-857.

15. Harboe, M., Quayle, A. J. (1991) Heat shock proteins: friend or foe?, Clin. Exp. Immunol. 86, 2-5.

16. Downes, C. P., Wolf, C. R., Lane, D. P. (eds) (1999) Cellular responses to stress. 1-171, Portland Press.

17. Lis, J. T., Wu, C. (1994) Transcriptional regulation of heat shock proteins. In: Transcription mechanisms and regulation. (Conaway, R. C., Conaway, J. W., eds), Raven Press, New York, 459-475.

18. Scharf, K. D., Hohfeld, I., Nover, L. (1998) Heat stress response and heat stress transcription factors. J. Biosci. 23, 313-329.

19. Gupta, R. S. (1998) Protein phylogenies and signature sequences: a reappraisal of evolutionary relationship among archaebacteria, eubacteria and fungi. Microbiol. Mol. Biol. Rev. 62, 1435-1491.

20. Srinivas, U. K., Swamynathan, S. K. (1996) Role of heat shock transcription factors in stress response and during development. J. Biosci. 21, 103-121.

21. Swamynathan, S. K., Revathi, C. J., Srinivas, U. K. (1996) Identification and characterization of promoter elements responsible for the induction of the albumin gene by heat shock in early embryonic rat liver. DNA Cell. Biol. 15, 897-905.

22. Morange, M., Favet, N., Loones, M. T., Manuel, M., Mezger, V., Michel, E., Rallu, M., Sage, J. (1998) Heat shock genes and development. Ann. N. Y. Acad. Sci. 851, 117-122. 
23. Heydari, A. R., Takahashi, R., Gutsmann, A., You, S., Richardson, A. (1994) Hsp70 and aging. Experientia 50, 1092-1098.

24. Brown, I. R., Gozes, I. (1998) Stress genes in the nervous system during development and aging diseases. Ann. N. Y. Acad. Sci. 851, 123-128.

25. Moreira, M. E., Del Portillo, H. A., Milder, R. V., Balanco, J. M., Barcinski, M. A. (1996) Heat shock induction of apoptosis in promastigotes of the unicellular organism Leishmania (Leishmania) amazonensis. J. Cell. Physiol. 167, 305-313.

26. Samali, A., Orrenius, S. (1998) Heat shock proteins: regulators of stress response and apoptosis. Cell. Stress. Chaperones 3, 228-236.

27. Vayssier, M., Polla, B. S. (1998) Heat shock proteins chaperoning life and death. Cell. Stress. Chaperones 3, 221-227.

28. Gorman, A. M., Heavey, B., Creagh, E., Cotter, T. G., Samali, A. (1999) Antioxidant-mediated inhibition of the heat shock response leads to apoptosis. FEBS Lett 445, 98-102.

29. Chaloupka, J. (1994) Stresové bílkoviny a jejich funkce v buňce. Fórum Imunologie 3, 88-104.

30. Schlesinger, M. J. (1994) How the cell copes with stress and the function of heat shock proteins. Pediatr. Res. 36, 1-6.

31. Haas, I. G. (1994) BiP (GRP78), an essential hsp70 resident protein in the endoplasmic reticulum. Experientia 50, 1012-1020.

32. Barril, J. S., Kim, S. G., Batt, C. A. (1994) Cloning and sequencing of the Lactococcus lactis subsp. lactis dnaK gene using a PCR-based approach. Gene 142, 91-96.

33. Netzer, W. J., Hartl, F. U. (1998) Protein folding in the cytosol: chaperonin-dependent and -independent mechanisms. Trend Biochem Sci 23, 68-73.

34. Forreiter, C., Nover, L. (1998) Heat induced stress proteins and the concept of molecular chaperones. J. Biosci. 23, 287-302.

35. McMullin, T. W., Hallberg, R. L. (1988) A highly evolutionarily conserved mitochondrial protein is structurally related to the protein encoded by the Escherichia coli groEL gene. Mol. Cell. Biol. 8, 371-380.

36. Jindal, S., Dudani, A. K., Singh, B., Harley, C. B., Gupta, R. S. (1989) Primary structure of a human mitochondrial protein homologous to the bacterial and plant chaperonins and to the 65-kilodalton mycobacterial antigen. Mol Cell Biol 9, 2279-2283.

37. Cheng, M. Y., Hartl, F. U., Martin, J., Pollock, R. A., Kalousek, F., Neupert, W., Hallberg, E. M., Hallberg, R. L., Horwich, A. L. (1989) Mitochondrial heat-shock protein hsp60 is essential for assembly of proteins imported into yeast mitochondria. Nature 337, 620-625.

38. Coates, A. R., Shinnick, T. M., Ellis, R. J. (1993) Chaperonin nomenclature. Mol. Microbiol. 8, 787.

39. Lindguist, S., Craig, E. A. (1986) The heat-shock proteins Annu. Rev. Genet. 22, 631-677.

40. Kaufmann, S. H. E. (1994) Heat shock proteins and autoimmunity: A critical appraisal. Int Arch Allergy Appl Immunol 103, 317-322.

41. Shinnick, T. M., Vodkin, M. H., Williams, J. C. (1988) The Mycobacterium tuberculosis 65-kilodalton antigen is a heat shock protein which corresponds to common antigen and to the Escherichia coli GroEL protein. Infect Immun 56, 446-51.

42. Jaattela, M., Wissing, D. (1992) Emerging role of heat shock proteins in biology and medicine. Ann. Med. 24, 249-258.

43. Kopeček, P., Weigl, E. (1994) Biologické funkce stresových bílkovin. Zpravodaj klinické farmakologie a farmacie, Lékařská fakulta UP a Fakultní nemocnice v Olomouci 8, 32-35.

44. Tanguay, R. M., Joanisse, D. R., Inaguma, Y., Michaud, S. (1999) Small heat shock proteins: in search of functions in vivo. In Envinmental stress and gene regulation. (Storey K. B., ed.), BIOS Scientific Publishers Ltd, Oxford, pp. 125-138.

45. Parsell, D. A., Lindquist, S. (1993) The function of heat-shock proteins in stress tolerance: degradation and reactivation of damaged proteins Annu. Rev. Genet. 27, 437-496.

46. Gething, M. J., Sambrook, J. (1992) Protein folding in the cell. Nature 355, 33-45.

47. Schwartz, J. A., Mizukami, H., Skafar, D. F. (1993) A metallinked gapped zipper model is proposed for the hsp90-glucocorticoid receptor interaction. FEBS Lett 315, 109-113.
48. Carver, L. A., Jackiw, V., Bradfield, C. A. (1994) The 90-kDa heat shock protein is essential for $\mathrm{Ah}$ receptor signaling in a yeast expression system. J Biol Chem 269, 30109-30112.

49. Jakob, U., Buchner, J. (1994) Assisting spontaneity: the role of Hsp90 and small Hsps as molecular chaperones. Trend. Biochem. Sci 19, 205-211.

50. Lebeau, M. C., Baulieu, E. E. (1994) Steroid antagonists and receptor-associated proteins. Hum. Reprod. 9 (suppl. 2), 11-21.

51. Lebeau, M. C., Baulieu, E. E. (1994) Steroid antagonists and receptor-associated proteins. Hum Reprod 9, 437-44.

52. DeFranco, D. B., Ramakrishnan, C., Tang, Y. (1998) Molecular chaperones and subcellular trafficking of steroid receptors. J. Steroid. Biochem. Mol. Biol. 65, 51-58.

53. Liu, J., DeFranco, D. B. (1999) Chromatin recycling of glucocorticoid receptors: implications for multiple roles of heat shock protein 90. Mol Endocrinol 13, 355-365.

54. Pratt, W. B. (1993) The role of heat shock proteins in regulating the function, folding, and trafficking of the glucocorticoid receptor. J. Biol. Chem. 268, 21455-21458.

55. Hutchison, K. A., Dittmar, K. D., Pratt, W. B. (1994) All of the factors required for assembly of the glucocorticoid receptor into a functional heterocomplex with heat shock protein 90 are preassociated in a self-sufficient protein folding structure, a "foldosome". J Biol Chem 269, 27894-27899.

56. Shaknovich, R., Shue, G., Kohtz, D. S. (1992) Conformational activation of a basic helix-loop-helix protein (MyoD1) by the C-terminal region of murine HSP90 (HSP84). Mol. Cell. Biol. $12,5059-5068$

57. Xu, Y., Lindquist, S. (1993) Heat-shock protein hsp90 governs the activity of pp60v-src kinase. Proc. Nat. Acad. Sci. USA 90, 7074-7078.

58. Xu, Y., Singer, M. A., Lindquist, S. (1999) Maturation of the tyrosine kinase c-src as a kinase and as a substrate depends on the molecular chaperone Hsp90. Proc. Nat. Acad. Sci. USA 96, 109-114.

59. Yahara, I., Minami, Y., Miyata, Y. (1998) The 90-kDa stress protein, Hsp90, is a novel molecular chaperone. Ann. N. Y. Acad. Sci. 851, 54-60.

60. Wiech, H., Buchner, J., Zimmermann, R., Jakob, U. (1992) Hsp90 chaperones protein folding in vitro. Nature 358, 169-170.

61. Craig, E. A. (1993) Chaperones: helpers along the pathways to protein folding. Science 260, 1902-1903.

62. Becker, J., Craig, E. A. (1994) Heat-shock proteins as molecular chaperones. Eur. J. Biochem. 219, 11-23.

63. Frydman, J., Nimmesgern, E., Ohtsuka, K., Hartl, F. U. (1994) Folding of nascent polypeptide chains in a high molecular mass assembly with molecular chaperones. Nature 370,111-117.

64. Fink, A. L. (1999) Chaperone-mediated protein folding. Physiol Rev 79, 425-449.

65. Feige, U., Polla, B. S. (1994) Hsp70-a multi-gene, multi-structure, multi-function family with potential clinical applications. Experientia 50, 979-986.

66. Flaherty, K. M., DeLuca-Flaherty, C., McKay, D. B. (1990) Three-dimensional structure of the ATPase fragment of a 70K heat-shock cognate protein. Nature 346, 623-628.

67. Flaherty, K. M., McKay, D. B., Kabsch, W., Holmes, K. C. (1991) Similarity of the three-dimensional structures of actin and the ATPase fragment of a $70-\mathrm{kDa}$ heat shock cognate protein. Proc. Nat. Acad. Sci. USA 88, 5041-5045.

68. Flajnik, M. F., Canel, C., Kramer, J., Kasahara, M. (1991) Which came first, MHC class I or class II? Immunogenetics 33, 295-300.

69. Gunther, E., Walter, L. (1994) Genetic aspects of the hsp70 multigene family in vertebrates. Experientia 50, 987-1001.

70. Sargent, C. A., Dunham, I., Trowsdale, J., Campbell, R. D. (1989) Human major histocompatibility complex contains genes for the major heat shock protein HSP70. Proc. Nat. Acad. Sci. USA 86, 1968-1972.

71. Milner, C. M., Campbell, R. D. (1990) Structure and expression of the three MHC-linked HSP70 genes. Immunogenetics $32,242-251$. 
72. Hendershot, L. M., Valentine, V. A., Lee, A. S., Morris, S. W., Shapiro, D. N. (1994) Localization of the gene encoding human $\mathrm{BiP} / \mathrm{GRP} 78$, the endoplasmic reticulum cognate of the HSP70 family, to chromosome 9q34. Genomics 20, 281-284.

73. Wurst, W., Benesch, C., Drabent, B., Rothermel, E., Benecke, B. J., Gunther, E. (1989) Localization of heat shock protein 70 genes inside the rat major histocompatibility complex close to class III genes. Immunogenetics 30, 46-49.

74. Cameron, P. U., Tabarias, H. A., Pulendran, B., Robinson, W., Dawkins, R. L. (1990) Conservation of the central MHC genome: PFGE mapping and RFLP analysis of complement, HSP70, and TNF genes in the goat. Immunogenetics 31, 253-264.

75. Grosz, M. D., Womack, J. E., Skow, L. C. (1992) Syntenic conservation of HSP70 genes in cattle and humans. Genomics 14, 863-868.

76. Nunes, M., Yerle, M., Dezeure, F., Gellin, J., Chardon, P., Vaiman, M. (1993) Isolation of four HSP70 genes in the pig and localization on chromosomes 7 and 14. Mamm Genome 4, 247-251.

77. Salter-Cid, L., Kasahara, M., Flajnik, M. F. (1994) Hsp70 genes are linked to the Xenopus major histocompatibility complex. Immunogenetics 39, 1-7.

78. Lindquist, S. (1986) The heat-shock response. Ann. Rev. Biochem. 55, 1151-91.

79. Tilly, K., McKittrick, N., Zylicz, M., Georgopoulos, C. (1983) The dnaK protein modulates the heat-shock response of Escherichia coli. Cell 34, 641-646.

80. Straus, D. B., Walter, W. A., Gross, C. A. (1988) Escherichia coli heat shock gene mutants are defective in proteolysis. Genes. Dev. 2, 1851-1858.

81. Straus, D. B., Walter, W. A., Gross, C. A. (1990) DnaK, DnaJ, and GrpE heat shock proteins negatively regulate heat shock gene expression by controlling the synthesis and stability of sigma 32. Genes. Dev. 4, 2202-2209.

82. Shi, W., Zhou, Y., Wild, J., Adler, J., Gross, C. A. (1992) DnaK, DnaJ, and GrpE are required for flagellum synthesis in Escherichia coli. J. Bacteriol. 174, 6256-6263.

83. Russell, R., Jordan, R., McMacken, R. (1998) Kinetic characterization of the ATPase cycle of the DnaK molecular chaperone. Biochemistry 37, 596-5607.

84. Russell, R., Wali Karzai, A., Mehl, A. F., McMacken, R. (1999) DnaJ dramatically stimulates ATP hydrolysis by DnaK: insight into targeting of Hsp70 proteins to polypeptide substrates. Biochemistry 28, 4165-4176.

85. Karzai, A. W., McMacken, R. (1996) A bipartite signaling mechanism involved in DnaJ-mediated activation of the Escherichia coli DnaK protein. J. Biol. Chem. 271, 11236-11246.

86. Brodsky, J. L., Goeckeler, J., Schekman, R. (1995) BiP and Sec63p are required for both co- and posttranslational protein translocation into the yeast endoplasmic reticulum. Proc. Nat. Acad. Sci. USA 92, 9643-9646.

87. Gaston, J. S. (1992) Are heat shock proteins involved in autoimmunity? Int. J. Clin. Lab. Res. 22, 90-94.

88. Mollenhauer, J., Schulmeister, A. (1992): The humoral immune response to heat shock proteins. Experientia 48, 644-649.

89. de Graeff-Meeder, E. R., van Eden, W., Rijkers, G. T., Prakken, B. J., Kuis, W., Voorhorst-Ogink, M. M., Marleen, M., van der Zee, R., Schuurman, H. J., Helders, P. J. M., Zegers, B. J. M. (1995) Juvenile chronic arthritis: T cell reactivity to human HSP60 in patients with a favorable course of arthritis. J. Clin. Invest. 95, 934-940.

90. Peeling, R. W., Bailey, R. L., Conway, D. J., Holland, M. J., Campbell, A. E., Jallow, O., Whittle, H. C., Mabey, C. W. (1998) Antibody response to the 60-kDa chlamydial heat-shock protein is associated with scarring trachoma. J. Infect. Dis. 177, 256-259.

91. Luft, B. J., Gorevic, P. D., Jiang, W., Munoz, P., Dattwyler, R. J. (1991) Immunologic and structural characterization of the dominant 66- to $73-\mathrm{kDa}$ antigens of Borrelia burgdorferi. J. Immunol. 146, 2776-2782.

92. Dieterle, S., Wollenhaupt, J. (1996) Humoral immune response to the chlamydial heat shock proteins hsp60 and hsp70 in
Chlamydia-associated chronic salpingitis with tubal occlusion. Hum Reprod 11, 1352-1356.

93. Kakeya, H., Udono, H., Ikuno, N., Yamamoto, Y., Mitsutake, K., Miyazaki, T., Tomono, K., Koga, H., Tashiro, T., Nakayama, E., Kohno, S. (1997) A 77-kilodalton protein of Cryptococcus neoformans, a member of the heat shock protein 70 family, is a major antigen detected in the sera of mice with pulmonary cryptococcosis. Infect Immun 65, 1653-1658.

94. Tilly, K., Murialdo, H., Georgopoulos, C. (1981) Identification of a second Escherichia coli groE gene whose product is necessary for bacteriophage morphogenesis. Proc. Nat. Acad. Sci. USA 78, 1629-1633.

95. Hemmingsen, S. M., Woolford, C., van der Vies, S. M., Tilly, K., Dennis, D. T., Georgopoulos, C. P., Hendrix, R. W., Ellis, R. J. (1988) Homologous plant and bacterial proteins chaperone oligomeric protein assembly. Nature 333, 330-334.

96. Reading, D. S., Hallberg, R. L., Myers, A. M. (1989) Characterization of the yeast HSP60 gene coding for a mitochondrial assembly factor. Nature 337, 655-659.

97. Hutchinson, J. P., el-Thaher, T. S., Miller, A. D. (1994) Refolding and recognition of mitochondrial malate dehydrogenase by Escherichia coli chaperonins cpn 60 (groEL) and cpn10 (groES). Biochem. J. 302, 405-410.

98. Gatenby, A. A, Viitanen, P. V. (1994) Structural and functional aspects of chaperonin-mediated protein folding. Annu. Rev. Plant. Physiol. Plant. Mol. Biol. 45, 469-491.

99. Viitanen, P. V., Lorimer, G. H., Seetharam, R., Gupta, R. S., Oppenheim, J., Thomas, J. O., Cowan, N. J. (1992) Mammalian mitochondrial chaperonin 60 functions as a single toroidal ring. J. Biol. Chem. 267, 695-698.

100. Miller, S. G., Leclerc, R. F., Erdos, G. W. (1990) Identification and characterization of a testis-specific isoform of a chaperonin in a moth, Heliothis virescens. J. Mol. Biol. 214, 407-422.

101. Musgrove, J. E., Johnson, R. A., Ellis, R. J. (1987) Dissociation of the ribulosebisphosphate-carboxylase large-subunit binding protein into dissimilar subunits. Eur. J. Biochem. 163, 529-534.

102. Martel, R., Cloney, L. P., Pelcher, L. E., Hemmingsen, S. M. (1990) Unique composition of plastid chaperonin-60: alpha and beta polypeptide-encoding genes are highly divergent. Gene 94, 181-187.

103. Roy, H., Bloom, M., Milos, P., Monroe, M. (1982) Studies on the assembly of large subunits of ribulose bisphosphate carboxylase in isolated pea chloroplasts. J. Cell. Biol. 94, 20-27.

104. Azem, A., Kessel, M., Goloubinoff, P. (1994) Characterization of a functional GroEL14(GroES7)2 chaperonin hetero-oligomer. Science 265, 653-656.

105. Yura, T., Nagai, H., Mori, H. (1993) Regulation of the heatshock response in bacteria. Annu. Rev. Microbiol. 47, 321-350.

106. Gilmour, D. S., Lis, J. T. (1985) In vivo interactions of RNA polymerase II with genes of Drosophila melanogaster. Mol. Cell. Biol. 5, 2009-2018.

107. Sorger, P. K. (1990) Yeast heat shock factor contains separable transient and sustained response transcriptional activators. Cell. 62, 793-805.

108. Eissenberg, J. C., Cartwright, I. L., Thomas, G. H., Elgin, S. C. (1985) Selected topics in chromatin structure. Annu. Rev. Genet. 19, 485-536.

109. Lodish, H, Baltimore, D., Berk, A, Zipursky, S. L., Matsudaira, P., Darnell, J. (1995) Regulation of transcription initiation. In Molecular Cell. Biology, (3rd ed.), Scientific American Books, New York, 405-484.

110. Stoltz, G. (1999) An RNA Thermomether. Genes. Dev. 13, 633-636.

111. Straus, D. B., Walter, W. A., Gross, C. A. (1987) The heat shock response of $E$. coli is regulated by changes in the concentration of sigma 32 . Nature 329, 348-351.

112. Fujita, N., Ishihama, A. (1987) Heat-shock induction of RNA polymerase sigma-32 synthesis in Escherichia coli: transcriptional control and a multiple promoter system. Mol. Gen. Genet. 210, 10-15.

113. Erickson, J. W., Gross, C. A. (1989) Identification of the sigma E subunit of Escherichia coli RNA polymerase: a second alternate sigma factor involved in high-temperature gene expression. Genes. Dev. 3, 1462-1471. 
114. Crickmore, N., Salmond, G. P. (1986) The Escherichia coli heat shock regulatory gene is immediately downstream of a cell division operon: the fam mutation is allelic with rpoH. Mol. Gen. Genet. 205, 535-539.

115. Yura, T., Nakahigashi, K., Kanemori, M. (1996) Transcriptional regulation of stress-inducible genes in procaryotes. EXS 77, 165-181.

116. Ramirez-Santos, J., Gomez-Eichelmann, M. C. (1998) Identification of sigma 32-like factors and ftsX-rpoH gene arrangements in enteric bacteria. Can. J. Microbiol. 44, 565-568.

117. Wang, Q. P., Kaguni, J. M. (1989) dnaA protein regulates transcriptions of the $\mathrm{rpoH}$ gene of Escherichia coli. J. Biol. Chem. 264, 7338-7344.

118. Nagai, H., Yano, R., Erickson, J. W., Yura, T. (1990) Transcriptional regulation of the heat shock regulatory gene $\mathrm{rpoH}$ in Escherichia coli: involvement of a novel catabolite-sensitive promoter. J. Bacteriol. 172, 2710-2715.

119. Schultz, J. E., Latter, G. I., Matin, A. (1988) Differential regulation by cyclic AMP of starvation protein synthesis in Escherichia coli. J. Bacteriol. 170, 3903-3909.

120. Laskowska, E., Kuczynska-Wisnik, D., Skorko-Glonek, J., Taylor, A. (1996) Degradation by proteases Lon, Clp and HtrA, of Escherichia coli proteins aggregated in vivo by heat shock; HtrA protease action in vivo and in vitro. Mol. Microbiol. 22, 555-571.

121. Skorko-Glonek, J., Wawrzynow, A., Krzewski, K., Kurpierz, K., Lipinska, B. (1995) Site-directed mutagenesis of the HtrA (DegP) serine protease, whose proteolytic activity is indispensable for Escherichia coli survival at elevated temperatures. Gene 163, 47-52.

122. Amin, J., Ananthan, J., Voellmy, R. (1988) Key features of heat shock regulatory elements. Mol. Cell. Biol. 8, 3761-3769.

123. Westwood, J. T., Wu, C. (1993) Activation of Drosophila heat shock factor: conformational change associated with a monomer-to-trimer transition. Molecular and Cellular Biology 13, 3481-3486.

124. Wisniewski, J., Orosz, A., Allada, R., Wu, C. (1996) The C-terminal region of Drosophila heat shock factor (HSF) contains a constitutively functional transactivation domain. Nucleic Acids Res 24, 367-374.

125. Nover, L., Scharf, K. D., Gagliardi, D., Vergne, P., CzarneckaVerner, E., Gurley, W. B. (1996) The Hsf world: classification and properties of plant heat stress transcription factors. Cell. Stress. Chaperones 1, 215-223.

126. Perisic, O., Xiao, H., Lis, J. T. (1989) Stable binding of Drosophila heat shock factor to head-to-head and tail-to-tail repeats of a conserved 5 bp recognition unit. Cell 59, 797-806.

127. Mager, W. H., Ferreira, P. M. (1993) Stress response of yeast. Biochem. J. 290, 1-13.

128. Larson, J. S., Schuetz, T. J., Kingston, R. E. (1988) Activation in vitro of sequence-specific DNA binding by a human regulatory factor. Nature 335, 372-375.

129. Cotto, J. J., Morimoto, R. I. (1999) Stress induced activation of the heat-shock response: cell and molecular biology of heatshock factors. In Cellular responses to stress. (Downes C. P., Wolf C. R., Lane D. P., eds), Portland Press, pp. 105-118.

130. Hartl, F. U. (1996) Molecular chaperones in cellular protein folding. Nature 381, 571-579.

131. Martin, J., Hartl, F. U. (1997) Chaperone-assisted protein folding. Curr. Opin. Struct. Biol. 7, 41-52.

132. Landry, S. J., Gierasch, L. M. (1994) Polypeptide interactions with molecular chaperones and their relationship to in vivo protein folding. Annu. Rev. Biophys. Biomol. Struct. 23, 645-669.

133. Schmid, F. X. (1993) Prolyl isomerase: enzymatic catalysis of slow protein-folding reactions. Annu. Rev. Biophys. Biomol. Struct. 22, 123-42.

134. Wang, C. C., Tsou, C. L. (1998) Enzymes as chaperones and chaperones as enzymes. FEBS Lett 425, 382-384.
135. Nover, L., Scharf, K. D. (1997) Heat stress proteins and transcription factors. Cell. Mol. Life Sci. 53, 80-103.

136. Palleros, D. R., Shi, L., Reid, K. L., Fink, A. L. (1994) hsp70protein complexes. Complex stability and conformation of bound substrate protein. J. Biol. Chem. 269, 13107-13114.

137. Kabakov, A. E., Gabai, V. L. (1994) Heat-shock proteins mantain the viability of ATP-deprived cells: what is the mechanism? Trend. Cell. Biol. 4, 193-196.

138. Zhu, X., Zhao, X., Burkholder, W. F., Gragerov, A., Ogata, C. M., Gottesman, M. E., Hendrickson, W. A. (1996) Structural analysis of substrate binding by the molecular chaperone DnaK. Science 272, 1606-1614.

139. James, P., Pfund, C., Craig, E. A. (1997) Functional specificity among Hsp70 molecular chaperones. Science 275, 387-389.

140. Osipiuk, J., Walsh, M. A., Freeman, B. C., Morimoto, R. I., Joachimiak, A. (1999) Structure of a new crystal form of human Hsp70 ATPase domain. Acta Crystallogr. D 55, 1105-1107.

141. Bukau, B., Horwich, A. L. (1998) The Hsp70 and Hsp60 chaperone machines. Cell 92, 351-366.

142. Pfanner, N., Craig, E. A., Honlinger, A. (1997) Mitochondrial preprotein translocase. Annu. Rev. Cell. Dev. Biol. 13, 25-51.

143. Sigler, P. B., Xu, Z., Rye, H. S., Burston, S. G., Fenton, W. A., Horwich, A. L. (1998) Structure and function in GroEL-mediated protein folding. Annu. Rev. Biochem. 67, 581-608.

144. Baneyx, F., Gatenby, A. A. (1993) GroEL mediated protein folding. In Protein folding in vivo and in vitro. (Cleland J. L., ed.), American Chemical Society, Wahington DC, 133-141.

145. Chen, S., Roseman, A. M., Hunter, A. S., Wood, S. P., Burston, S. G., Ranson, N. A., Clarke, A. R., Saibil, H. R. (1994) Location of a folding protein and shape changes in GroELGroES complexes imaged by cryo-electron microscopy. Nature $371,261-264$.

146. Shtilerman, M., Lorimer, G. H., Englander, S. W. (1999) Chaperonin function: folding by forced unfolding. Science 284, 822-825.

147. Ellis, R. J., Hartl, F. U. (1996) Protein folding in the cell: competing models of chaperonin function. FASEB J 10, 20-26.

148. Todd, M. J., Viitanen, P. V., Lorimer, G. H. (1994) Dynamics of the chaperonin ATPase cycle: implications for facilitated protein folding. Science 265, 659-666.

149. Sosnick, T. R., Mayne, L., Hiller, R., Englander, S. W. (1994) The barriers in protein folding. Nat. Struct. Biol. 1, 149-156.

150. Schmidt, M., Buchner, J., Todd, M. J., Lorimer, G. H., Viitanen, P. V. (1994) On the role of groES in the chaperonin-assisted folding reaction. Three case studies. J. Biol. Chem. 269, 10304-10311.

151. Ranson, N. A., White, H. E., Saibil, H. R. (1998) Chaperonins. Biochem. J. 333, 233-242.

152. Dubaquie, Y., Looser, R., Rospert, S. (1997) Significance of chaperonin 10-mediated inhibition of ATP hydrolysis by chaperonin 60. Proc. Nat. Acad. Sci. USA 94, 9011-9016.

153. Richardson, A., Landry, S. J., Georgopoulos, C. (1998) The ins and outs of a molecular chaperone machine. Trend. Biochem. Sci. 23, 138-143.

154. Stuart, R. A., Cyr, D. M., Neupert, W. (1994) Hsp70 in mitochondrial biogenesis: from chaperoning nascent polypeptide chains to facilitation of protein degradation. Experientia 50, 1002-1011.

155. Spiess, C., Beil, A., Ehrmann, M. (1999) A temperature-dependent switch from chaperone to protease in a widely conserved heat shock protein. Cell 97, 339-347.

156. Muller, S., Schwartz, L. M. (1995) Ubiquitin in homeostasis, development and disease. Bioessays 17, 677-684.

157. Dohmen, R. J., Stappen, R., McGrath, J. P., Forrova, H., Kolarov, J., Goffeau, A., Varshavsky, A. (1995): An essential yeast gene encoding a homolog of ubiquitin-activating enzyme. J. Biol. Chem. 270, 18099-18109.

158. Craig, E. A., Gross, C. A. (1991): Is hsp70 the cellular thermometer? Trend. Biochem. Sci. 16, 135-140. 